Dept. of Animal Medicine,

Faculty of Veterinary Medicine,

Assiut University, Assiut 71526, Egypt

Corresponding author: aref71@hotmail.com

\title{
SOME INDICES OF METABOLIC PROFILE AND OXIDATIVE STRESS IN SOHAGI EWES DURING \\ TRANSITION PERIOD
}

(With 2 Tables and One Figure)

\author{
By \\ N-E. MOHAMED AREF and H.A. HAMDON \\ * Dept of Animal and Poultry Production, Faculty of Agriculture, Sohag \\ University, 82786 Egypt. \\ (Received at 8/12/2011)
}
بعض مؤشرات التمثيل الفذائي وضغوط الأكسدة في النعاج السوهاجي خلال

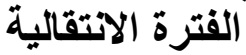

$$
\text { نصر اللدين محد عارف ، حاتم عبل القادر حددن }
$$

اجريت هذة الدراسة لتقدير بعض مؤشرات التمثيل الغذائى وضغوط الاكسدة فى النعاج

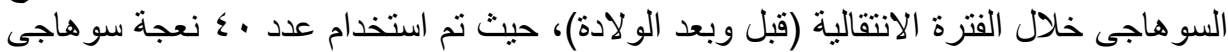

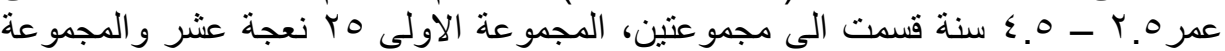

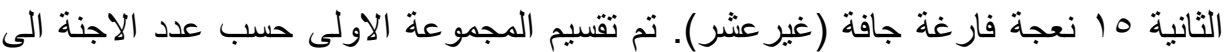

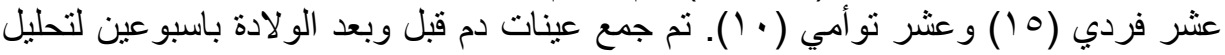

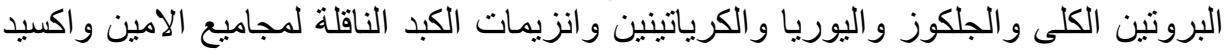

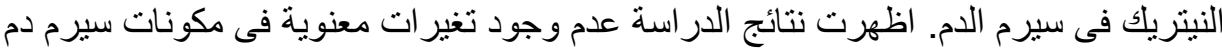

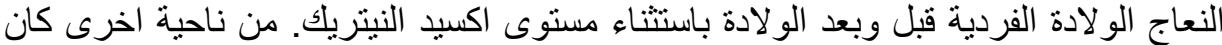

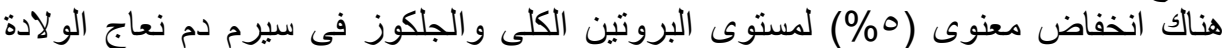

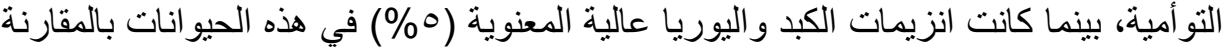

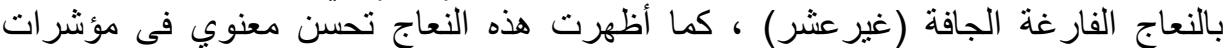

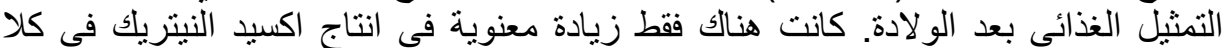

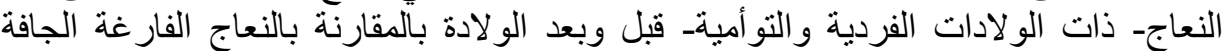

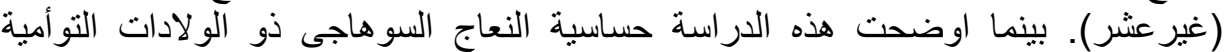

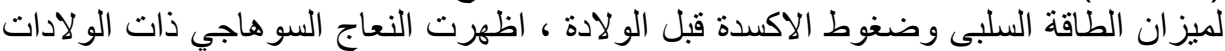

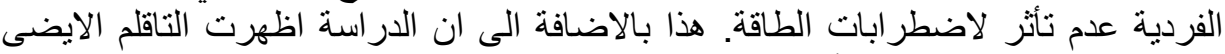

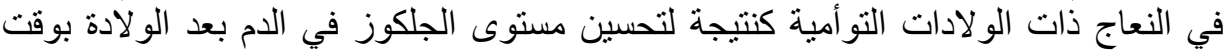




\section{SUMMARY}

The present study was carried out to assess some metabolic indices and nitric oxide in sexually mature, cycling; apparently healthy Sohagi ewes during transition period. At the beginning of the study, 40 ewes were randomly separated into two main groups: pregnant $(n=25)$ and non pregnant $(\mathrm{n}=15)$ groups. Pregnant group was further subdivided retrospectively into single and twin bearing ewes' subgroups. Blood samples were collected from both main groups. Samples from pregnant ewes were collected at two weeks before and after parturition. Samples were assayed for serum total protein, glucose, urea nitrogen, creatinine, aspartate aminotransferase (AST), alanine aminotransferase (ALT), and nitric oxide. The results of this study showed no marked change in serum metabolites in single-bearing transition Sohagi ewes except for nitric oxide level. On the other hand, significantly lower $(\mathrm{p}<0.05)$ levels of serum total protein and glucose concentrations were recorded in twin-bearing ewes while liver enzymes and serum urea nitrogen showed significant higher $(\mathrm{p}<0.05)$ compared to control group. Marked improvement in serum metabolites had been recorded after parturition. Only level of nitric oxide production showed significant increase in both single and twin-bearing ewes before parturition compared to control one. While this study indicates the susceptibility of full-term twin-bearing pregnant Sohagi ewes to negative energy balance and oxidative stress before parturition, it showed tolerance of single-bearing pregnant ewes to energy disturbance. Additionally, twin-bearing pregnant Sohagi ewes showed high degree of metabolic adaptation as indicated by remarkable improvement in the blood glucose level shortly after parturition.

Key Words: Transition period, Sohagi ewes, Energy balance, Nitric oxide.

\section{INTRODUCTION}

There has been much interest over the past two decades to study the impact of transition (peripartum) period on animal health, reproduction and lactational performance in food animals. While several studies have been conducted in particular, on dairy cows (Shaver 1993; Grant and Albright 1995; James and Drackley 1999; Bernal-Santos 
et al., 2003; Pushpakumara et al., 2003; Zachut et al., 2010; Silvestre et al., 2011; do Amaral et al., 2011), little was carried out on transition ewes. Current research concepts regarding metabolic alterations associated with transition ewes may be extrapolated from dairy cattle, however unexpected metabolic changes may occur. Several factors undoubtedly influence the metabolic process during transition period. Nutrition and energy demand, in particular are essential factors in the adaptation process of metabolism in pregnant ewes. Decreasing dry matter intake (DMI) and decreasing ruminal capacity in the last trimester stage can lead to negative energy balance and subsequent pregnancy toxemia (Radostits et al., 2007; Schlumbohm and Harmeyer, 2008). High energy demand associated with rapid fetal growth during the last weeks of gestation contributes also negatively on energy balance of pregnant ewes. The influence of other factors such as body condition score is not fully understood because contradicted results were recorded in different studies (Kahn and Line, 2005). Nowadays scientists think about genetic predisposition in the metabolism of fat and carbohydrates in some breeds (Graber et al., 2010).

The present study was designed to determine some indices of metabolic and oxidative stress in Sohagi ewes breed during transition period. The effects of pregnancy and parturition on some biochemical and oxidative parameters including total protein, blood glucose, blood urea nitrogen, creatinine, serum aspartate aminotransferase (AST), alanine aminotransferase (ALT), and nitric oxide were studied on sexually mature Sohagi ewes during transition period.

\section{MATERIALS and METHODS}

Animals and breed characteristics: Sohagi sheep flock had been formed by the College of Agriculture, University of Sohag in 2001. The breed was registered by Domestic Animal Genetic Resources Information System -International Livestock Research Institute, Addis Ababa, Ethiopia as an additional breed of sheep (DAGRIS- ILRI, 2007; Mahfouz et al., 2008). Animals are shallow body, medium in size with long neck and legs. Head is medium with straight profile and ewes are mostly polled while rams are horned. Body is covered with coarse wool ranging from cream to white in color. Head is generally dark brown or creamy with dark rings around eyes. Ears are vestigial and tail varies in shape from wide base terminated into a sort segment to a lesser wide 
base ending into cylindrical part extending well below the hocks. (Hamdon, 2009).

Experimental design: The study was conducted on 40 sexually mature, cycling; apparently healthy Sohagi ewes with an average body weight $36.10 \pm 0.66$ and age ranged from 2.5 to 4.5 years. Ewes were randomly divided into two main groups according to their pregnancy: Pregnant $(\mathrm{n}=25)$ and non pregnant $(\mathrm{n}=15)$. Pregnant group was further subdivided retrospectively into single and twin bearing subgroups. Blood samples were collected from both main groups. Samples from pregnant group were taken at two weeks before and after parturition. Samples were assayed for total protein, blood glucose, blood urea nitrogen, creatinine, serum aspartate aminotransferase (AST), alanine aminotransferase (ALT), and nitric oxide. The experiment acts in accordance with the guidelines and recommendations for the Institutional Animal Care and Use Committee of Sohagi University.

Study area: This experiment was carried out at the animal production experimental farm, Faculty of Agriculture, Sohag University, Sohag, Upper Egypt. The flock was housed in semi open pens, fed concentrates and roughage. Hay and green fodder (Trifolium Alexandrium and Sorghim) were used as roughages, free access to water and block common salt. Parturitions took place in February, June and October. Lambs were kept with their dams in individual boxes for three days after birth.

\section{Clinical parameters}

A clinical chart was designed to record various clinical indices of health. The appetite, dry matter intake, behavior and mental status (Demeanor) of transient ewes were monitored by inspection. Body temperature and pulse rate were digitally recorded using pulse oximeter for veterinary use (Model 340V, CA-USA).

\section{Blood sampling}

Blood samples were collected from pregnant and non pregnant groups. Pregnant ewes were sampled on days -14 and +14 , from parturition. Samples were collected in clean, dry centrifuge tubes without anticoagulant. The samples were left for $30 \mathrm{~min}$. at room temperature until clotting and then centrifuged at $3000 \mathrm{rpm}$ for 20 minutes (Coles and Rich, 1992). The obtained clear non hemolyzed sera were separated and transferred into clean epindorff vials and then stored 
at $-20{ }^{\circ} \mathrm{C}$ for determination of blood glucose, total protein, blood urea nitrogen, creatinine, serum AST, ALT and nitric oxide.

\section{Biochemical assays}

All reagents and kits used in this study were previously tested in our laboratory. Spectrophotometric method by using Phillips Pye Unicam spectrophotometer (U.V. visible Mod. 800) was adopted to determine serum concentrations of the following constituents: glucose (Trinder), total protein (Biuret), urea (Urease-glutamate dehydrogenase), creatinine (Jaff'e reaction), AST and ALT (International Federation of Clinical Chemistry-modified method). All kits and reagents were obtained from Spectrum Reagents (Egyptian Company for Biotechnology, Cairo, Egypt).

\section{Nitric oxide determination}

Nitric oxide (NO) in biological systems was measured indirectly by reaction kinetics according to Green et al. (1982).

\section{Statistical analysis}

Statistical Package for the Social Sciences program for windows version 10.0.1 (SPSS, 1999) was used to analyze the obtained data. All data were presented as mean \pm standard error (SE). Differences between groups were determined by LSD Post hoc test. Significance level was set at $\mathrm{P} \leq 0.05$.

\section{RESULTS}

\section{Clinical course}

No signs of clinical toxemia of pregnancies such as star gazing, recumbency and coma were recorded in pregnant ewes during the period of study. Sohagi ewes in last trimester stage of pregnancy were alert and able to stand without assistant but reluctant to move with slight reduction in feed intake. Body temperature $\left({ }^{\circ} \mathrm{C}\right)$ and pulse rate (beats/min) were $39.3 \pm 0.20,93 \pm 6$, and $85 \pm 5$, respectively. Recently parturient ewes showed slight decrease in DMI, mild pyrexia $(39.5 \pm$ $0.50)$ and tachycardia $(103 \pm 5)$ in first 24 hours postpartum.

\section{Finding of serum biochemical analysis}

Levels of indices under study in terms of serum glucose, total protein, urea, creatinine, liver enzymes and nitric oxide concentrations evaluated in blood serum in transition Sohagi ewes were presented in Tables 1 and 2 . 


\section{Serum total protein and glucose concentrations}

Serum total protein concentrations 14 days before and after parturition were $5.77 \pm 0.17 \mathrm{~g} / \mathrm{dl}$ and $6.25 \pm 0.18 \mathrm{~g} / \mathrm{dl}$, respectively in single-bearing ewes while they were significantly decrease $(p<0.05)$ in twin-bearing ewes (4.42 \pm 0.23 and $4.95 \pm 0.15 \mathrm{~g} / \mathrm{dl}$, respectively) compared to control one ((Figure 1A). Non significant improvement was recorded in serum total protein concentration before and after parturition in twin bearing animals. On the other hand, serum glucose level was significantly lower $(\mathrm{p}<0.05)$ in twin-bearing group $(53.76 \pm 2.50 \mathrm{mg} / \mathrm{dl})$ before parturition compared to control one $(62.70 \pm 1.44 \mathrm{mg} / \mathrm{dl})$. Marked improvement (significantly increase, $\mathrm{p}<0.05$ ) was shown in serum glucose level $(66.62 \pm 1.39 \mathrm{mg} / \mathrm{dl})$ two weeks after parturition in twin bearing animals. Single bearing ewes showed no significant change in their serum glucose level (Figure 1B).

\section{Serum urea and creatinine concentrations}

Mean serum urea concentration in twin-bearing ewes before parturition were significantly higher $(30.93 \pm 2.88 \mathrm{mg} / \mathrm{dl})$ compared to control one $(24.65 \pm 1.05 \mathrm{mg} / \mathrm{dl})$, however significant improvement was recorded after parturition in the same group (Figure 1B). Serum creatinine concentrations showed no significant difference among different groups (Figure 1A).

\section{Liver Enzymes}

AST and ALT enzyme activities were significantly higher $(124.18 \pm 4.76$ and $50.41 \pm 2.25 \mathrm{U} / 1)$ in twin-bearing $(72.26 \pm 1.40$ and $35.10 \pm 1.40 \mathrm{U} / \mathrm{l})$ compared to control one, however they showed marked reduction in their activities after parturition. No significant changes in the activity of liver enzymes among single bearing animals (Figure 1B).

\section{Nitric oxide production}

Nitrite levels as an indication of nitric oxide production had been showed to be significantly elevated in both single and twin-bearing groups before parturition compared to control group. Slight but not significantly, improvement in NO concentrations was recorded postpartum in both groups (Figure 1A). 
Table 1: Mean ( \pm S.E.) of some metabolic indices concentration in transition Sohagi ewes regardless type of bearing

\begin{tabular}{|l|c|c|c|}
\hline \multirow{2}{*}{ Parameter } & \multirow{2}{*}{$\begin{array}{c}\text { Non pregnant } \\
(\mathrm{n}=15)\end{array}$} & \multicolumn{2}{c|}{ Pregnant $(\mathrm{n}=25)$} \\
\cline { 3 - 4 } & $6.28 \pm 0.22$ & $5.24 \pm 0.18^{\mathrm{ab}}$ & $5.74 \pm 0.18$ \\
\hline $\mathrm{TP}(\mathrm{g} / \mathrm{dl})$ & $62.70 \pm 1.44$ & $58.50 \pm 1.41^{\mathrm{ab}}$ & $63.40 \pm 0.96$ \\
\hline $\begin{array}{l}\text { Glucose } \\
(\mathrm{mg} / \mathrm{dl})\end{array}$ & $24.65 \pm 1.05$ & $27.54 \pm 1.46^{\mathrm{ab}}$ & $25.77 \pm 1.05$ \\
\hline Urea $(\mathrm{mg} / \mathrm{dl})$ & $0.96 \pm 0.30$ & $1.01 \pm 0.03$ & $0.99 \pm 0.04$ \\
\hline $\begin{array}{l}\text { Creatinine } \\
(\mathrm{mg} / \mathrm{dl})\end{array}$ & $35.10 \pm 1.40$ & $43.33 \pm 1.93^{\mathrm{ab}}$ & $38.39 \pm 1.23$ \\
\hline ALT $(\mathrm{U} / \mathrm{l})$ & $72.26 \pm 1.40$ & $94.88 \pm 5.69^{\mathrm{ab}}$ & $80.39 \pm 2.91$ \\
\hline AST $(\mathrm{U} / \mathrm{l})$ & $2.18 \pm 0.10$ & $4.21 \pm 0.24^{\mathrm{ab}}$ & $3.64 \pm 0.19$ \\
\hline NO $(\mu \mathrm{M} / \mathrm{l})$ & & & \\
\hline
\end{tabular}

Table 2: Mean ( \pm S.E.) of some metabolic indices concentration in single and twin -bearing transition Sohag ewes

\begin{tabular}{|c|c|c|c|c|c|}
\hline \multirow{3}{*}{ Parameter } & \multirow{3}{*}{$\begin{array}{l}\text { Non } \\
\text { pregnant } \\
(\mathrm{n}=15)\end{array}$} & \multicolumn{4}{|c|}{ Pregnant $(n=25)$} \\
\hline & & \multicolumn{2}{|c|}{$\begin{array}{l}\text { Single } \\
(\mathrm{n}=15)\end{array}$} & \multicolumn{2}{|c|}{$\begin{array}{c}\text { Twin } \\
(\mathrm{n}=10)\end{array}$} \\
\hline & & Pre & Post & Pre & Post \\
\hline $\mathrm{TP}(\mathrm{g} / \mathrm{dl})$ & $6.28 \pm 0.22$ & $5.77 \pm 0.17$ & $6.25 \pm 0.18$ & $\begin{array}{l}4.49 \pm \\
0.21^{\mathrm{ab}}\end{array}$ & $4.95 \pm 0.15$ \\
\hline $\begin{array}{l}\text { Glucose } \\
(\mathrm{mg} / \mathrm{dl})\end{array}$ & $62.70 \pm 1.44$ & $\begin{array}{c}61.79 \pm \\
0.93\end{array}$ & $\begin{array}{c}61.34 \pm \\
0.98\end{array}$ & $\begin{array}{c}53.76 \pm \\
2.50^{\mathrm{ab}}\end{array}$ & $\begin{array}{c}66.62 \pm \\
1.39\end{array}$ \\
\hline Urea $(\mathrm{mg} / \mathrm{dl})$ & $24.65 \pm 1.05$ & $\begin{array}{c}25.19 \pm \\
1.15\end{array}$ & $\begin{array}{c}24.74 \pm \\
1.02\end{array}$ & $\begin{array}{c}30.93 \pm \\
2.88^{\mathrm{ab}}\end{array}$ & $\begin{array}{c}27.86 \pm \\
2.34\end{array}$ \\
\hline $\begin{array}{l}\text { Creatinine } \\
(\mathrm{mg} / \mathrm{dl})\end{array}$ & $0.96 \pm 0.30$ & $1.01 \pm 0.06$ & $0.99 \pm 0.06$ & $1.02 \pm 0.03$ & $0.93 \pm 0.23$ \\
\hline ALT (U/1) & $35.10 \pm 1.40$ & $\begin{array}{c}38.43 \pm \\
1.95\end{array}$ & $\begin{array}{c}37.17 \pm \\
1.57\end{array}$ & $\begin{array}{c}50.41 \pm \\
2.25^{\text {ab }}\end{array}$ & $\begin{array}{c}40.30 \pm \\
1.92\end{array}$ \\
\hline AST (U/l) & $72.26 \pm 1.40$ & $\begin{array}{c}74.59 \pm \\
1.26\end{array}$ & $\begin{array}{c}72.87 \pm \\
1.16\end{array}$ & $\begin{array}{c}124.18 \pm \\
4.76^{\mathrm{ab}}\end{array}$ & $\begin{array}{c}92.09 \pm \\
5.30\end{array}$ \\
\hline $\mathrm{NO}(\mu \mathrm{M} / \mathrm{l})$ & $2.18 \pm 0.10$ & $\begin{array}{c}3.80 \pm \\
0.26^{\mathrm{a}}\end{array}$ & $3.47 \pm 0.25$ & $\begin{array}{c}4.79 \pm \\
0.38^{\mathrm{ab}} \\
\end{array}$ & $3.91 \pm 0.27$ \\
\hline
\end{tabular}

$\mathrm{a}=\mathrm{LSD}$ compared to non pregnant groups

$\mathrm{b}=\mathrm{LSD}$ before compared to after parturition 
Figure 1A.

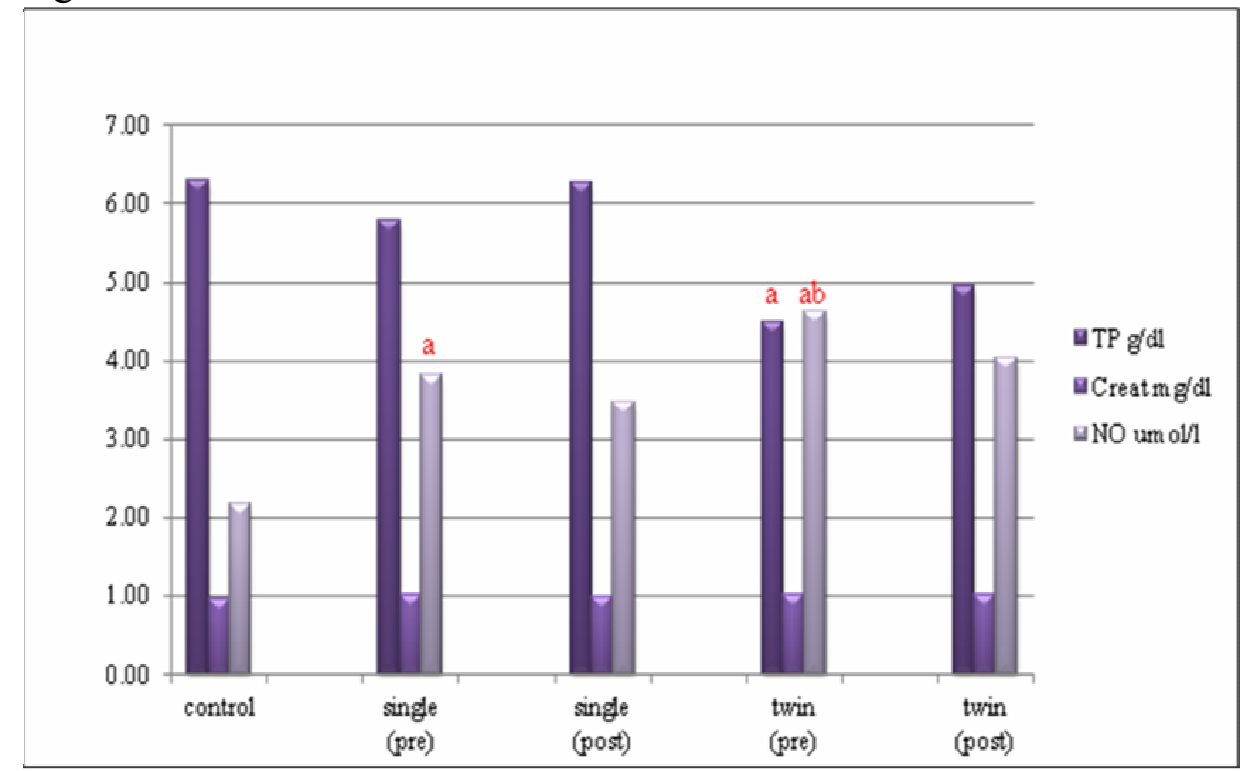

Figure 1B.

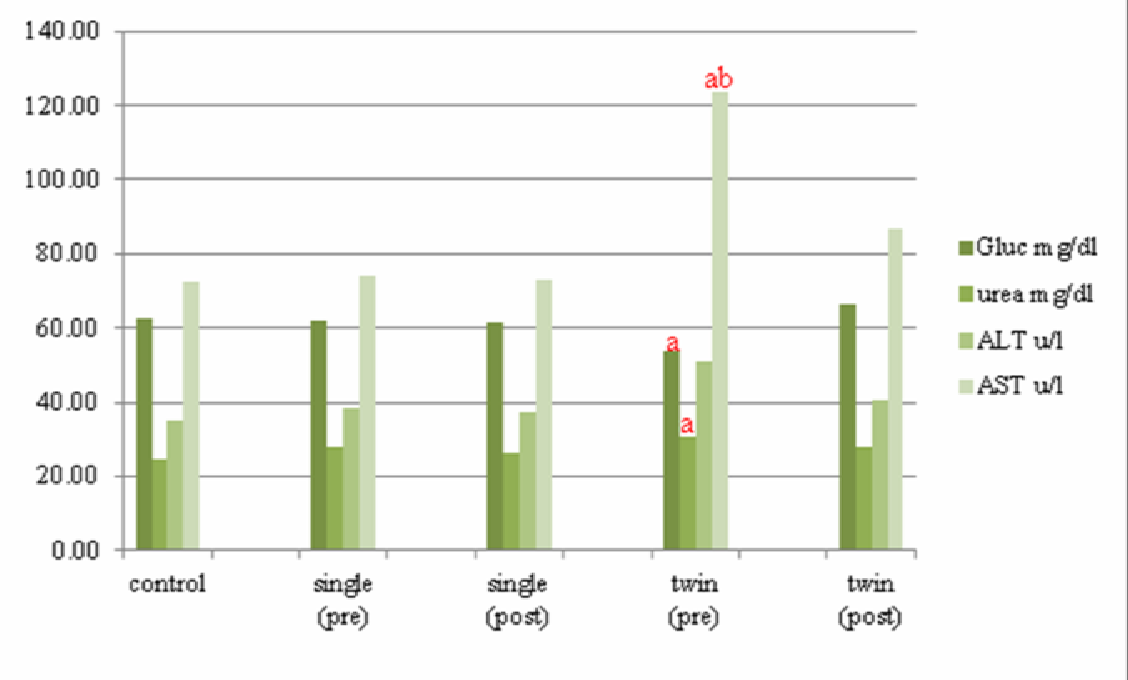

Mean value of TP, creatinine and nitric oxide (Fig. 1A), glucose, urea and liver enzymes (Fig. 1B) in non pregnant, single and twin bearing Sohagi ewes

$\mathrm{a}=\mathrm{LSD}$ compared to non pregnant group

$\mathrm{b}=\mathrm{LSD}$ before compared to after parturition subgroups 


\section{DISCUSSION}

Nutritional and other stress factors associated with pregnancy and parturition play a pivotal role in energy homeostasis. The nutritional requirements of ewes increase during late pregnancy due to the rapid fetal growth. Additionally, lactation in response to dramatic hormonal change during first few weeks of parturition puts further stress and increases energy demand. Improper management of ewes during transition period will result in negative energy balance due to lipomobilization in response to shortage in energy supply (Radostits et al., 2007).

\section{Serum glucose level}

Our data primary showed marked change in serum glucose level in the last two week of pregnancy irrespective to bearing type (Table 1). Further classification of pregnant ewes according to their bearing type revealed that twin bearing ewes were more susceptible to negative energy balance than single bearing ones, however marked improvement in serum glucose levels was recorded two weeks after parturition. The lower serum glucose levels in twin-bearing ewes in late pregnancy could be attributed to lipomobilization syndrome in response to high energy demand associated with pregnancy in more than one fetuses (Radostits et al., 2007). This finding was in an agreement with several authors (Bickhardt and KÖnig, 1985; Kleeman et al., 1988; Firat and Özpinar, 1996; Hamadeh et al., 1996; West, 1996). To contrary, some authors reported different findings of blood glucose level. Al-Dewachi (1999) reported high blood glucose levels in pregnant ewes while Vernon et al. (1981) did not record significant changes in serum glucose levels during pregnancy and lactation.

\section{Serum total protein}

A significant decrease in serum total protein level was also recorded in twin bearing ewes two weeks before and after parturition compared to non pregnant ewes while it showed no significant change in single bearing animals. Decrease in serum total protein may be attributed to increase demand for amino acids in response to fetal growth and colostrums production during late pregnancy and early parturition, respectively (Davson and Segal, 1980; Jainudee and Hafez, 1994). To contrary, Brozostowski et al. (1996); El-Sherif and Assad (2001) reported gradually increase of total protein to the reference value during lactation (Kaneko, 1989) but they reported similar findings in late 
pregnancy. Similarly, Gonzales-Montana et al. (1994) reported twin pregnancies produce significantly lower protein levels when compared to a single pregnancy.

\section{Serum urea and creatinine}

In this study, while serum urea level was higher in twin bearing animals two week before parturition, mild improvement has been noticed after parturition. Similarly, El-Sherif and Assad (2001) reported serum urea to increase in pregnant ewes from $10^{\text {th }}$ week of pregnancy, reaching a maximum level at parturition. The evaluation in serum urea nitrogen may be due to reduced glomerular filtration and urea clearance in ewes during late pregnancy and lactation (Rodriguez et al., 1996). Contrary, Firat and Özpinar (1996) recorded insignificant differences in serum urea levels between multiple and single pregnancy in sheep. No significant changes were recorded in creatinine level in different groups in the present study.

\section{Liver enzyme}

ALT and AST activities showed no rise in single bearing animals while they showed significant increase in twin bearing ewes in the last two week of pregnancy. This temporary rise of liver enzyme in twin bearing ewes could be due to lipomobolization syndrome (Radostits et al., 2007).

Nitric oxide

Nitrite concentrations in single and twin bearing ewes were increased. The increased nitrite concentrations reflect the increased nitric oxide synthesis, which may in part mediate the cardiovascular adaptations to stress associated with pregnancy and parturition (Yang et al., 1996).

\section{CONCLUSION}

This study showed that changes occur in the blood metabolite concentrations during transition period in Sohag ewes. The magnitude of these changes was greater in twin-bearing sheep which could be attributed to increased nutrient demands in response to fetal growth. In conclusion, the present study has indicated that energy imbalance is likely to occur in twin bearing Sohagi ewes during transition period while both single and twin bearing Sohag ewes were susceptible to oxidative stress. 


\section{REFERENCES}

Al-Dewachi, O.S. (1999): Some biochemical constituents in the blood serum of pregnant Awassi ewes. Iraqi J. Vet. Sci. 12: 275-279.

Bernal-Santos, G.J.; Perfield, J.W.; Barbano, D.M.; Bauman, D.E. and Overton, T.R. (2003): Production responses of dairy cows to dietary supplementation with conjugated linoleic acid (cla) during the transition period and early lactation 1 and 2. J. Dairy Sci. 86: 3218-3228.

Bickhardt, K. and KÖnig, G. (1985): Blutmesswerte von gesunden mutterschafen der Merino-und Schwarzkopfrasse zur zeit der geburt. Dtsch. Tier" arztl. Wochenschr. 92: 319-322.

Brozostowski, H.; Milewski, S.; Wasilewska, A. and Tanski, Z. (1996): The influence of the reproductive cycle on levels of some metabolism indices in ewes. Arch. Vet. Polonic. 35: 53-62.

Coles, E.H. and Rich, L.J. (1992): Veterinary Laboratory Medicine. WB Saunders Co, Philadelphia, Pennsylvania, USA. 1st edn.. ISBN 0-7216-2654-8.

Dagris-Ilri, (2007): Domestic Animal Genetic Resources Information System (DAGRIS): International Livestock Research Institute (ILRI), Addis Ababa, Ethiopia.

Davson, H. and Segal, M.B. (1980): Pregnancy: maintenance and prevention. In: Introduction to Physiology, Vol. 5: Control of Reproduction.Academic Press, London, pp. 258-288.

Do Amaral, B.C.; Connor, E.E.; Tao, S.; Hayen, M.J.; Bubolz, J.W. and Dahl, G.E. (2011): Heat stress abatement during the dry period influences metabolic gene expression and improves immune status in the transition period of dairy cows. J. Dairy Sci. 94: 86-96.

El-Sherif, M.M. and Assad, F. (2001): Changes in some blood constituents of Barki ewes during pregnancy and lactation under semi arid conditions. Small Rumin. Res. 40: 269-277.

Firat, A. and Özpinar, A. (1996): The study of changes in some blood parameters (glucose, urea, bilirubin, AST) during and after pregnancy in association with nutritional conditions and litter size in ewes. Tr. J. Vet. Anim. Sci. 20: 387-393.

Gonzales-Montana, J.R.; Alonso-Diez, A.J.; Alonso-Alonso, M.P.; Prieto-Montana, F.; Garcia-Partida, P. and Trenti, F. (1994): Serum protein levels during pregnancy in sheep. In: 
Proceedings of the $18^{\text {th }}$ World Buiatrics Congress, Bologna, Italy, pp. 1181-1184.

Graber, M.; Kohler, S.; Kaufmann, T.; Doherr, M.G.; Bruckmaier, R.M. and Van Dorland, H.A. (2010): A field study on characteristics and diversity of gene expression in the liver of dairy cows during the transition period. J Dairy Sci. 11: 5200-15.

Grant, R.J. and Albright, J.L. (1995): Feeding behavior and management factors during the transition period in dairy cattle. J. Animal Sci. 73: 2791-2803.

Green, L.C.; Wagner, D.A.; Glogowski, J.; Skipper, P.L.; Wishnok, J.S. and Tannenbaum, S.R. (1982): Analysis of nitrate, and [15N] nitrate in biological fluids. Anal. Biochem. 1: 131-138.

Hamadeh, M.E.; Bostedt, H. and Failing, K. (1996): Concentration of metabolic parameters in the blood of heavily pregnant and nonpregnant ewes. Berl. Munch. Tier"arztl. Wochenschr. 109: $81-86$.

Hamdon, H. (2009): Milk production characterization of Sohagi sheep. Assuit J. Agr. Sci. 40: 13-26.

Jainudee, M.R. and Hafez, E.S. (1994): Gestation, prenatal physiology and parturition. In: Hafez, E.S.E. (Ed.), Reproduction in Farm Animals. Lea and Febiger, Philadelphia, pp. 247-283.

James, K. and Drackley, A. (1999): Biology of dairy cows during the transition period: The final frontier? J. Dairy Sci. 82: 2259-2273.

Kahn, C.M. and Line, S. (2005): Pregnancy toxemia in ewes. In The Merck Veterinary Manual. 9th ed. Merck \& Co Whitehouse Station pp 828-830.

Kaneko, J.J. (1989): Clinical Biochemistry of Domestic Animals. Academic Press Inc., London.

Kleeman, D.O.; Smith, D.H.; Walker, S.K. and Walkley, J.R.W. (1988): Plasma glucose levels in South Australian Merino Ewes. Aust. Vet. J. 65: 99-100.

Mahfouz, E.R.; Othman, E.O.; El Nahas, S.M. and El Barody, M.A. (2008): Genetic Variation Between Some Egyptian Sheep Breeds Using RAPD-PCR Research Journal of Cell and Molecular Biology, 2: 46-52.

Pushpakumara, P.G.; Gardner, N.H.; Reynolds, C.K.; Beever, D.E. and Wathes, D.C. (2003): Relationships between transition period diet, metabolic parameters and fertility in lactating dairy cows Theriogenology, 60: 1165-1185. 
Radostits, O.M.; Gay, C.C.; Hinchcliff, K.W. and Constable, P.D. (2007): Pregnancy toxemia in sheep. In: Veterinary Medicine A textbook of the diseases of cattle, horses, sheep, pigs and goats. 10th ed. Saunders Elsevier Philadelphia pp 1668-1670.

Rodriguez, M.N.; Tebot, I.; Bas, A.; Niievas, C.; Leng, L.; Cirio, A. and Le Bas, A. (1996): Renal functions and urea handling in pregnant and lactating Corriedale ewes. Can. J. Anim. Sci. 76: 469-472.

Schlumbohm, C. and Harmeyer, J. (2008): Twin-pregnancy increases susceptibility of ewes to hypoglycaemic stress and pregnancy toxaemia. Res. Vet. Sci. 84: 286-299.

Shaver, R.D. (1993): TMR strategies for transition feeding of dairy cows. In: J. Linn, G. Wagner, and P. DeSteno (Ed.) $54^{\text {th }}$ Minnesota Nutr. Conf. and Natl. Renderers Tech. Symp. Pp 163-183. Bloomington, MN.

Silvestre, F.T.; Carvalho, T.S.; Francisco, N.; Santos, J.E.; Staples, C.R.; Jenkins, T.C. and Thatcher, W.W. (2011): Effects of differential supplementation of fatty acids during the peripartum and breeding periods of Holstein cows: I. Uterine and metabolic responses, reproduction, and lactation. J. Dairy Sci. 94: 189-204.

Spss, (1999): Statistical Package for the Social Sciences program for windows version 10.0.1. SPSS Inc. Chicago. IL.

Vernon, R.G.; Clegg, R.A. and Flint, D.J. (1981): Metabolism of sheep adipose tissue during pregnancy and lactation. Biochem. J. 200: 307-314.

West, H.J. (1996): Maternal undernutrition during late pregnancy in sheep. Its relationship to maternal condition, gestation length, hepatic physiology and glucose metabolism. Br. J. Nutr. 75: 593-605.

Yang, D.; Lang, U.; Greenberg, S.G.; Myatt, L. and Clark, K.E. (1996): Elevation of nitrate levels in pregnant ewes and their fetuses. Am J Obstet Gynecol.174: 573-577.

Zachut, M.; Arieli, A.; Lehrer, H.; Livshitz, L.; Yakoby, S. and Moallem, $U$. (2010): Effects of increased supplementation of n-3 fatty acids to transition dairy cows on performance and fatty acid profile in plasma, adipose tissue, and milk fat. J Dairy Sci. 93: 5877-89. 